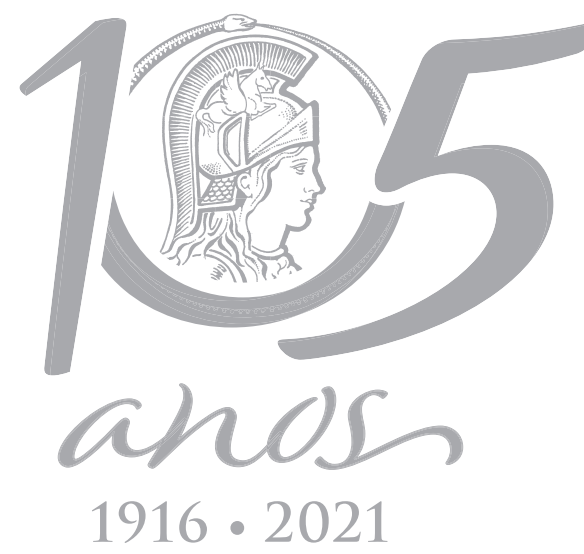

\title{
ECOSYSTEMS
}

\section{First description of wild-collected ephyrae of Lychnorhiza lucerna (Cnidaria, Scyphozoa)}

\author{
RENATO M. NAGATA, PRISCILA TEIXEIRA-AMARAL, VITÓRIA R. LEMOS, \\ MAYARA A. JORDANO, ERIK MUXAGATA \& ANDRÉ C. MORANDINI
}

\begin{abstract}
Ephyrae are the young scyphozoan jellyfishes that usually passes unnoticed, whereas their adult counterparts play major ecological roles and can negatively affect economic activities when they occur in high densities. We describe, for the first time, wild ephyrae of Lychnorhiza lucerna (Scyphozoa, Rhizostomeae) from the Patos Lagoon Estuary, Southern Brazil. A total of 10 ephyrae were found in salinities between 12 and 33 and temperatures between 16 and $27^{\circ} \mathrm{C}$. The presence of digitata, eight oral arms and serrated tips on marginal lobes allowed species determination. Wild ephyrae were morphologically identical to laboratory-cultivated individuals. The youngest individual was about one to two days old, and the most developed one, between 12 and 14 days old. Recruitment of L. lucerna probably initiated during warmer months (December until February) because nine out of ten individuals were found in high temperature $\left(>20^{\circ}\right.$ C) and salinity (> 30) waters. On the other hand, a mid-winter occurrence of a single ephyra $\left(T=16^{\circ} \mathrm{C}, \mathrm{S}=12\right)$ demonstrates that the species may support a considerable range of variation in the physical environment. We reinforce the importance of long-term studies to provide information about the species coupling with seasonal cycles and the dynamics of estuarine and coastal areas.
\end{abstract}

Key words: gelatinous zooplankton, long-term research, planktonic cnidarians, population dynamics, scyphomedusae.

\section{INTRODUCTION}

Ephyrae are the young scyphozoan jellyfishes that measure a few millimeters and last a few weeks in the plankton, before the development into adult medusae. Ephyrae are released from scyphistomae (the benthic scyphozoan polyps) and they undergo a drastic morphological change and fast growth during their initial development (Schiariti et al. 2008). Because ephyrae are often inconspicuous and ephemeral, they usually pass unnoticed, whereas their adult counterparts can play major ecological roles and negatively affect several economic activities when they occur in high densities in coastal areas (Purcell et al. 2007, Nagata et al.
2009). The detection of this short-lived stage in nature can be useful for understanding environmental drivers of medusae production by scyphistomae, which, in turn, can be useful for detecting early stages of jellyfish mass occurrences (Straehler-Pohl \& Jarms 2010, Holst 2012). Specific determination however, can be challenging, because of the similar body-plans of scyphozoan ephyrae (Russell 1970), which are still unknown for many species (Holst 2012), although some efforts in identification have been made (Straehler-Pohl \& Jarms 2010). The majority of the known scyphozoan ephyrae were obtained from laboratory cultures (Pitt 2000, Straehler-Pohl \& Jarms 2010), but a considerable number of species is known from nature 
(Uchida 1926, Palmén 1954, Tronolone et al. 2002, Toyokawa et al. 2012). This study describes, for the first time, ephyrae of the South American rhizostome medusa Lychnorhiza lucerna Haeckel, 1880 (Scyphozoa, Rhizostomeae) in its natural environment, found in coastal plankton samples from the Patos Lagoon Estuary (PLE), Southern Brazil.

Lychnorhiza lucerna is one of the most common and large scyphozoan medusae from the southwestern Atlantic (Oliveira et al. 2016). This species occurs from the northern Argentinean coast to the Caribbean Sea (Morandini et al. 2006, Oliveira et al. 2016) and, during its seasonal blooms, large medusae aggregations negatively affect local fisheries by clogging and damaging fishing gear (Schiariti et al. 2008, 2018, Nagata et al. 2009). Because L. lucerna is a key species on coastal marine ecosystems of South America, several aspects of its ecological role have been investigated, including trophic interactions (Nagata et al. 2015), symbiosis (Morandini et al. 2005a, Nogueira Jr \& Haddad 2005, Martinelli Filho et al. 2008, Gonçalves et al. 2016), and the species' diet and feeding rates (Nagata \& Morandini 2018). The metagenetic life cycle of L. lucerna was described (Schiariti et al. 2008) and variables influencing the species asexual reproduction have been experimentally tested (Schiariti et al. 2014). In laboratory, the scyphistomae produce ephyrae continuously, which have been used for experimental studies investigating predation (Carrizo et al. 2016), feeding biomechanics (Nagata et al. 2016) and developmental patterns (Jordano et al. 2020). These ephyrae, however, were rarely been found in its environment (Nogueira Jr et al. 2019, Teixeira-Amaral et al. 2021), and wild-specimens had never been morphologically characterized, which represented an important gap on the knowledge about their initial growth in nature. Medusae of L. lucerna had already been found in the PLE (Montú et al. 1998a, b), but there was no detailed information associated to its sampling (e.g. if inside or outside of the Patos Lagoon). Nonetheless, this medusa is, common and widely known by local fishermen and researchers because of the summer mass occurrences that usually clog fyke nets inside the estuary, negatively affecting local pink shrimp fisheries (RM Nagata personal observation).

The Patos-Mirim Lagoon System, receives water from a large drainage basin $(\approx 200,000$ $\mathrm{km}^{2}$ ), extending over southern Brazil and northern Uruguay, in the subtropical eastern South America (32S) (Figure 1) (Asmus 1998). The PLE area comprises about $10 \%$ of the southern end of the Patos Lagoon and is characterized by high primary and secondary productivity (Odebrecht et al. 2017, Abreu et al. 2017, Teixeira-Amaral et al. 2017), and is used as a nursery for larval stages of many fishes and crustaceans, including species of commercial interest (Sinque \& Muelbert 1998). Studies about the zooplankton community of the PLE were initiated in the early 1970s, emphasizing the role of hydrological regimes and seasonal cycles over the local assemblages (Montú 1980) and more recently on seasonal copepod productivity cycles (Muxagata et al. 2012, Teixeira-Amaral et al. 2017). In the PLE and adjacent coastal waters, more than 1,000 plankton samples have been analyzed in studies of plankton community (Montú 1980, Bersano 1994, Montú et al. 1998a, b, Kaminski 2009, Teixeira-Amaral et al. 2017, 2021). Although the focus of these studies was mainly on crustaceans, a considerable number of planktonic cnidarian taxa had already been found (Montú et al. 1998b, Teixeira-Amaral et al. 2021) and the only a mention of ephyrae of L. lucerna in the PLE was of two specimens found by Teixeira-Amaral et al. (2021). Here, we described the morphology of wild-collected ephyrae of L. lucerna and compared these, with 

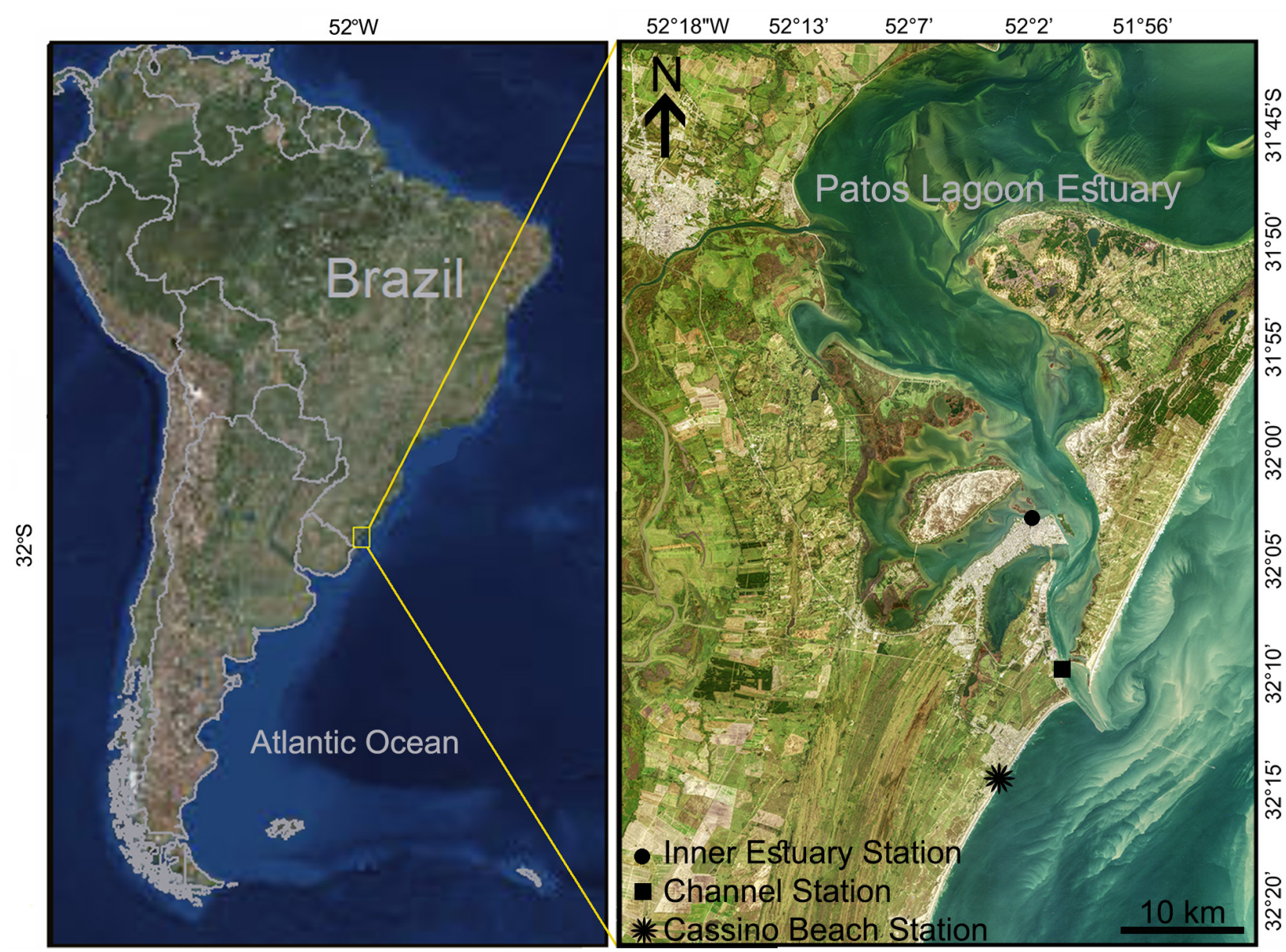

Figure 1. Map of South America (Source: ArcGIZ Desktop 8.1), with emphasis on the Southern Brazil, where the outlet of the Patos Lagoon Estuary is localized (Source: Landsat-8). Three sampling stations were disposed close to this outlet, two inside the Patos Lagoon Estuary (Inner and Channel stations) and one on the adjacent coastal area (Cassino Beach station).

laboratory cultivated individuals. We inferred the age of wild ephyrae, by the comparison with laboratory cultivated individuals, to discuss the timing of release and the possible location of their scyphistomae.

\section{MATERIALS AND METHODS}

Standardized continuous sampling of the zooplankton community has been conducted in the PLE since 2009, in the scope of the Long-Term Ecological Research Program (PELD). Samples were collected weekly to monthly during austral summer (late-December to early-March) and fortnightly to monthly during the remaining seasons. Sub-superficial horizontal hauls were carried out with plankton nets of 90 to $200 \mu \mathrm{m}$ mesh sizes, and $0.3 \mathrm{~m}$ mouth opening diameter (Table I). Description of sampling methods, abiotic data and of the influence of hydrology over the plankton community between 2009 and 2013 are available in Teixeira-Amaral et al. $(2017,2021)$ and they are similar to the sampling done from 2013 to 2019. Samples collected at the Cassino Beach, between November 2016 and March 2019 (Table I) were analyzed fresh under stereomicroscope, whereas the other samples were immediately preserved in $4 \%$ formaldehyde solution after samplings. 
Table I. Sampling effort performed between November 2009 and March 2019 along three sampling stations on the Patos Lagoon Estuary (PLE) and adjacent coastal waters, South Brazil. A total of 434 samples were analyzed in order to find ephyrae of Lychnorhiza lucerna Haeckel, 1880.

\begin{tabular}{|c|c|c|c|c|c|}
\hline Sampling Site & Net type & $\begin{array}{l}\text { Mesh Size } \\
(\mu \mathrm{m})\end{array}$ & $\begin{array}{l}\text { Sampling } \\
\text { frequency }\end{array}$ & Period & $\begin{array}{l}\text { Number of } \\
\text { analyzed } \\
\text { samples }\end{array}$ \\
\hline \multirow{2}{*}{ Cassino Beach } & \multirow{2}{*}{$\begin{array}{l}\text { Hensen } \\
\text { (horizontal } \\
\text { tows) }\end{array}$} & 200 & Monthly & Nov/2016 to Mar/2019 & 29 \\
\hline & & 200 & Monthly & Nov/2009 to Dec/2012 & 37 \\
\hline \multirow{2}{*}{ Channel } & \multirow{2}{*}{$\begin{array}{l}\text { Mini-Bongo } \\
\text { (horizontal } \\
\text { tows) }\end{array}$} & 200 & $\begin{array}{c}\text { Fortnightly } \\
\text { (during summer) }\end{array}$ & Apr/2009 to Mar/2013 & 98 \\
\hline & & 90 & $\begin{array}{l}\text { Monthly (weekly } \\
\text { during summer) }\end{array}$ & Apr/2009 to Apr/2010 & 18 \\
\hline \multirow{2}{*}{ Inner Estuary } & \multirow{2}{*}{$\begin{array}{l}\text { Mini-Bongo } \\
\text { (horizontal } \\
\text { tows) }\end{array}$} & 200 & $\begin{array}{l}\text { Fortnightly } \\
\text { (weekly during } \\
\text { summer) }\end{array}$ & Apr/2009 to Mar/2017 & 234 \\
\hline & & $90 \mu \mathrm{m}$ & $\begin{array}{l}\text { Monthly (weekly } \\
\text { during summer) }\end{array}$ & Apr/2009 to Mar/2010 & 18 \\
\hline
\end{tabular}

In laboratory, cultivated ephyrae used for a comparison with wild individuals were obtained from cultures of Lychnorhiza lucerna provided by Dr. Agustin Schiariti (Instituto Nacional de Investigación y Desarrollo Pesquero, INIDEP), from the region of Clamercó, NE coast of Argentina. These polyps were maintained in 200 $\mathrm{mL}$ flasks, in cultivation chambers with constant temperature of $20^{\circ} \mathrm{C}$, at the Laboratório de Cultivo e Estudos de Cnidaria (Instituto de Biociências-USP), Brazil. As soon as the polyps released the ephyrae, these were kept in Erlenmeyer flasks with aeration and fed daily with newly hatched Artemia sp., in standard quantities (200 nauplii per ephyra). Individuals $(\mathrm{N}=9)$ were photographed with a digital camera (Nikon SMZ1000) attached to a stereomicroscope using the NIS-Elements BR software. Pictures were taken on alternate days until the 10th day, then every six days until the $35^{\text {th }}$, and these images were compared with the wild individuals. We emphasize that the estimated age of these ephyrae is an approximation, because changes in environmental variables, such as temperature and quantity and quality of food will lead to differences in development (Jordano et al. 2020). This estimation was based on the emergence of key features during early morphogenesis (development of digitata, the bifurcation of oral arms, the filling of gaps between rhopalial lobes) rather than size that is decreased due to shrinkage in preserved specimens.

\section{RESULTS}

From 434 samples (Table I), we analyzed more than 20,000 individuals of planktonic cnidarians (see Teixeira-Amaral et al. 2021) and only ten ephyrae of Lychnorhiza lucerna were found, present in four samples (Table II). No individual was found at the innermost estuary station (Figure 1) and most individuals ( $n=9$ ) were found from December to February in relatively high temperature $\left(T>21^{\circ} \mathrm{C}\right)$ and salinity $(\mathrm{S}>32)$ waters. Voucher specimens were deposited in the Cnidaria collection of the Museu de Zoologia, 
Table II. Samples that contained Lychnorhiza lucerna Haeckel, 1880 ephyrae and the number of individuals found per sample (N) at the Patos Lagoon Estuary and adjacent coastal waters.

\begin{tabular}{|c|c|c|c|c|}
\hline Sampling Site & Sample date & Salinity & Temperature $\left({ }^{\circ} \mathrm{C}\right)$ & $\mathbf{N}$ \\
\hline \multirow{2}{*}{ Channel } & August $06^{\text {th }}, 2010$ & 12 & 16 & 1 \\
\hline & February $02^{\text {nd }}, 2013$ & 33 & 24 & 1 \\
\hline \multirow{2}{*}{ Cassino Beach } & January $07^{\text {th }}, 2014$ & 32 & 27 & 2 \\
\hline & December $04^{\text {th }}, 2018$ & 33 & 21 & 6 \\
\hline
\end{tabular}

Universidade de São Paulo (ephyra "3" as MZUSP 8466 and ephyra "8" as MZUSP 8467, Table III). Morphological descriptions of three ephyrae in distinct developmental stages (from recent released to an older ephyra) were provided, as follows:

Material examined: The smallest individual (ephyra "1", in Table III) was a supposed newly released ephyra (one to two days old) found at the Channel station (February 26 ${ }^{\text {th }}, 2013$ ). Description: Radial canals extending inside rhopalial lobes with distal dichotomic branches into slight lateral horns, which extend within the rhopalial lappets. Gastrovascular cavity of umbrella disc with initial elongation of the adradial canals, reaching the margin of the umbrella disc (Figure 2a). Velar lappets not developed. Eight rhopalial lobes, each one with two marginal antler palm-like rhopalial lappets (sensu Straehler-Pohl \& Jarms 2010). Each lappet with two tips bearing nematocyst clusters, the tips surrounding the rhopalial clefts longer than the adradial ones. U-shaped rhopalial clefts, with the length two to three times longer than the width. One or two gastric cirri per quadrant. Cruciform manubrium with four mouth lips elongating distally, reaching half of the umbrella disc diameter. One to three finger-like projections (digitata) over the margin of each distal elongation of the mouth lips. Digitata bearing nematocyst clusters on the tips.
Material examined: One of the older ephyrae with supposed age of six to eight days old (ephyra "8", Table III, MZUSP 8467), 3.4 mm of total umbrella diameter, found at the Cassino Beach station (December $12^{\text {th }}, 2018$ ).

Description: Eight rhopalial lobes, each one with two marginal antler palm-like rhopalial lappets (Figure 2b). Each lappet is serrate, with five to six tips of different sizes without a clear pattern of size distribution. These serrate tips bearing terminal nematocyst batteries consisting of small pear-shaped isorhiza $(<6 \mu \mathrm{m})$ and medium $(10 \mu \mathrm{m})$ rhopaloids (sensu Östman 2000). Velar lappets well developed (Figure $2 b$ ), one between each marginal lappet, some starting to become indented because of the presence of small serrate tips similar to those on rhopalial lappets. Three to four gastric cirri per quadrant. The first bifurcation of the four mouth lips developed into the eight oral arms, in an initial stage of differentiation. Initial oral arms $1.6 \mathrm{~mm}$ long. Digitata covering the edges of the mouth lips, each digitata with a nematocyst cluster on its tip consisting of medium $(\sim 10 \mu \mathrm{m})$ rhopaloid (Figure 2c). Gastrovascular cavity of umbrella disc occupying half of the total disc diameter. No nematocyst wart on exumbrella. Club-shaped adradial canals reaching the umbrella margin but not extending inside velar lappets (Figure 2b). Radial canals slightly forked to spade-like. 
Table III. Morphological and morphometric features of Lychnorhiza lucerna Haeckel, 1880 ephyrae found in the Patos Lagoon Estuary and adjacent coastal waters. The estimated age (days) was inferred upon the analysis of these features and a comparison with individuals cultivated in laboratory, from which the sequential morphogenesis during the transition from ephyrae to young medusae was followed. DBOR= Distance between opposite rhopalia $(\mathrm{mm})$, TBD=Total bell diameter $(\mathrm{mm})$, LEML=Length of ephyrae mouth lips $(\mathrm{mm})$, PDML=Presence of digitata on mouth lips, NVL= Number of velar lappets, FBOA= first bifurcation of oral arms, GCQ=Gastric cirri per quadrant, NTRL=Number of tips per rhopalial lappet, IA= Inferred age (days).

\begin{tabular}{|c|c|c|c|c|c|c|c|c|c|c|}
\hline $\begin{array}{l}\text { Ephyra } \\
\text { number }\end{array}$ & $\begin{array}{l}\text { Sampling } \\
\text { date }\end{array}$ & $\begin{array}{l}\text { DBOR } \\
(\mathrm{mm})\end{array}$ & $\begin{array}{c}\text { TBD } \\
(\mathrm{mm})\end{array}$ & $\begin{array}{l}\text { LEML } \\
(\mathrm{mm})\end{array}$ & PDML & NVL & FBOA & GCQ & NTRL & $\begin{array}{c}\text { IA } \\
\text { (days) }\end{array}$ \\
\hline 7 & $\begin{array}{l}\text { February } \\
26^{\text {th }}, 2013\end{array}$ & 1.4 & 2.0 & 0.45 & $\begin{array}{l}2 \text { or } 3 \\
\text { per lip }\end{array}$ & Absent & Absent & $1-2$ & 2 & 1 to 2 \\
\hline 6 & $\begin{array}{l}\text { August } \\
08^{\text {th }}, 2010\end{array}$ & 2.1 & 2.6 & 0.95 & Present & Absent & Absent & $2-3$ & $2-3$ & 3 to 4 \\
\hline 8 & $\begin{array}{l}\text { January } \\
07^{\text {th }}, 2014\end{array}$ & 1.9 & 2.7 & 0.75 & Present & Absent & Initial & $2-4$ & 3 & 3 to 4 \\
\hline 4 & $\begin{array}{c}\text { December } \\
04^{\text {th }}, 2018\end{array}$ & 2.2 & 2.6 & 1.20 & Present & Absent & Initial & $1-2$ & Damaged & 3 to 4 \\
\hline 9 & $\begin{array}{c}\text { January } \\
07^{\text {th }}, 2014\end{array}$ & 1.9 & 2.3 & 0.85 & Present & 1 & Initial & $1-2$ & 2 & 4 to 6 \\
\hline 3 & $\begin{array}{c}\text { December } \\
04^{\text {th }}, 2018\end{array}$ & 2.5 & 3.1 & 1.45 & Present & $1-2$ & Absent & 4-5 & $5-6$ & 4 to 6 \\
\hline 5 & $\begin{array}{c}\text { December } \\
04^{\text {th }}, 2018\end{array}$ & 3.4 & 4.1 & 1.55 & Present & 1 & Initial & $3-4$ & $6-7$ & 5 to 6 \\
\hline 2 & $\begin{array}{c}\text { December } \\
04^{\text {th }}, 2018\end{array}$ & 2.7 & 3.4 & 1.60 & Present & $1-2$ & Initial & $3-4$ & $5-6$ & 6 to 8 \\
\hline 1 & $\begin{array}{c}\text { December } \\
04^{\text {th }}, 2018\end{array}$ & 3.0 & 3.5 & $\begin{array}{l}\text { Mouth } \\
\text { lips } \\
\text { absent }\end{array}$ & $\begin{array}{l}\text { Mouth } \\
\text { lips } \\
\text { absent }\end{array}$ & 1 & $\begin{array}{l}\text { Mouth } \\
\text { lips } \\
\text { absent }\end{array}$ & Absent & $8-11$ & 8 to 9 \\
\hline 10 & $\begin{array}{c}\text { December } \\
04^{\text {th }}, 2018\end{array}$ & 8.1 & 10.5 & 5.50 & Present & 1 & Advanced & 5-10 & $8-13$ & $\begin{array}{l}12 \text { to } \\
14\end{array}$ \\
\hline
\end{tabular}

Commentaries: This ephyra had the closest developmental stage to the live individual of 10 days-old, shown in Figure 2d. Concerning the umbrella, the degree of development of the velar lappets are almost similar to both individuals, on the other hand, the oral arms were less developed in the preserved ephyra, than those of the ephyra reared in laboratory, in which the bifurcation of oral arms were more pronounced.

Material examined: One oldest ephyra (ephyra "10", Table III) was found in a fresh sample from the Cassino Beach station (December $12^{\text {th }}$, 2018). This individual was the most developed one (supposed age between 12 and 14 daysold), measuring about $10 \mathrm{~mm}$ of total umbrella diameter.

Description: Velar lappets almost completely filled the gap between adjacent rhopalial lappets. Both velar and rhopalial lappets bearing between eight and thirteen serrate tips (Figure 2d). Mesoglea thicker at the top of umbrella and umbrella height reached about one third of umbrella diameter. Lateral 


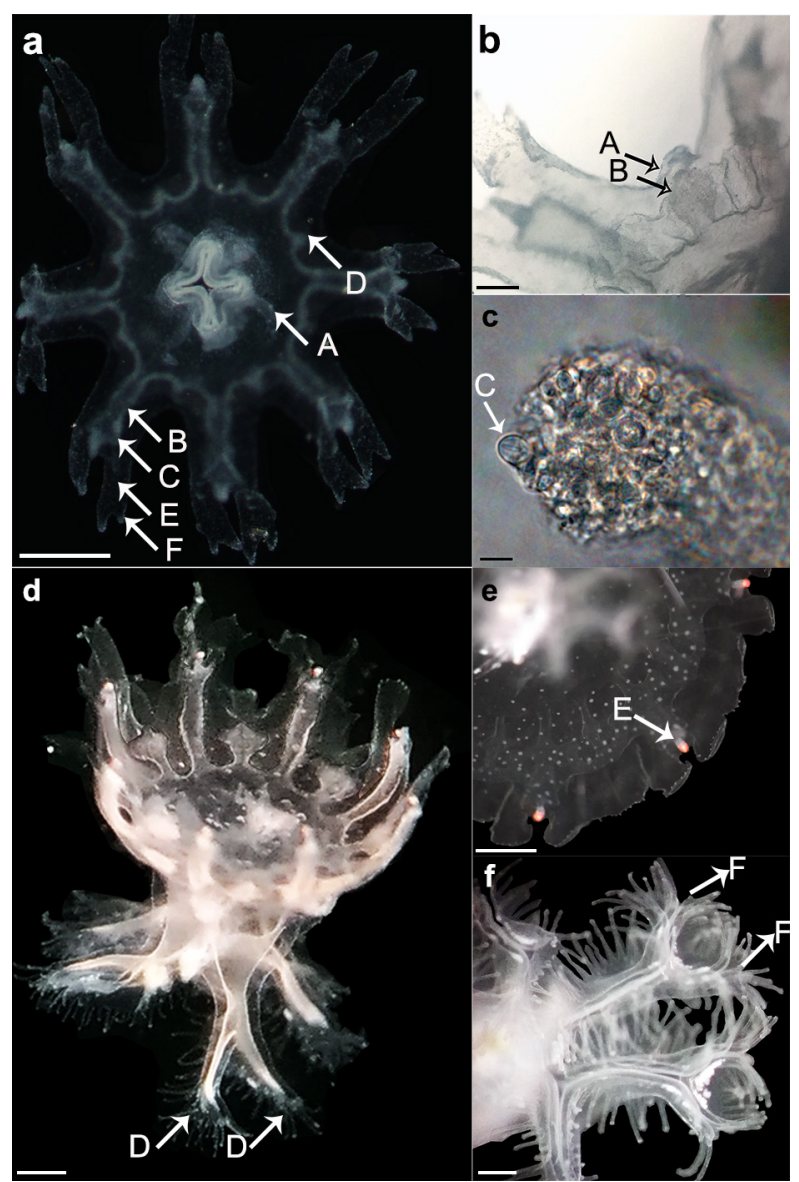

Figure 2. Ephyrae of Lychnorhiza lucerna found at the Patos Lagoon Estuary and adjacent coastal waters.

(a) A supposed recent-released (one to two days-old) ephyra found inside the PLE, showing: one gastric cirri (A); one radial canal (B); one distal branch of radial canal (C); the elongation of the adradial canal (D); one rhopalial lappet with two tips (E); and a tip of the rhopalial lappet with a nematocyst cluster at the distal end (F), scale bar: $500 \mu \mathrm{m}$. (b) Detail of an older ephyra (supposed 6 to 8 days-old), showing the gap between adjacent rhopalial lappets with a velar lappet (A) and the club-shaped adradial canal (B), scale bar: $50 \mu \mathrm{m}$. (c) Same individual as (b), detail of a digitata of the mouth lip showing a medium rhopaloid nematocyst (C), scale bar: $10 \mu \mathrm{m}$. (d) Live specimen, with the first bifurcation of the mouth lips giving rise to eight oral arms (D), scale bar: $100 \mu \mathrm{m}$.(e) The bell margin of the most developed individual analyzed (12 to 14 days-old), rhopalium (E) and gaps between adjacent rhopalial lappets completely filled by the development of velar lappets. (f) Same individual as (e), detail of the oral arms and the secondary terminal bifurcation giving rise to two external wings (F). projections of the adradial canals connected with lateral projections of the radial canals forming two concentric canal rings (Figure 2e). The external canal ring was close to the insertion of the rhopalium and the internal ring, in the midway between the center of the umbrella disc and umbrella margin. The tips of the oral-arms developed distally, reaching about half umbrella diameter. Bifurcations of the four oral lips were well defined, originating the eight oral arms and each oral arm had, in turn, a secondary terminal bifurcation, giving rise to the beginnings of two external wings (Figure 2f).

\section{DISCUSSION}

Although the general morphology of recently released ephyrae is similar among scyphomedusae, species can be determined by the shape and emergence of marginal lappets (Jordano et al. unpublished data), radial canals (Straehler-Pohl \& Jarms 2010) and the developmental patterns of the gastrovascular canal system (Russell 1970) and of the oral arms M.A. Jordano et al., (Jordano et al. unpublished data). The specimens here analysed are certainly of Lychnorhyza lucerna because: (1) the general shape is different from that of Coronatae ephyrae (e.g. Silveira \& Morandini 1997) showing the 8 marginal lobes, with 2 lappets each; (2) the presence of digitata on the mouth lips of these ephyrae excludes any Semaeostomeae species, except some Ulmaridae (Russell 1970; as oral tentacles); (3) older (>5 days-old) individuals had eight oral arms, absent in Semaeostomeae, that have four arms (Straehler-Pohl et al. 2011); (4) the presence of serrated tips (fingerlike projections) on marginal lappets excludes Ulmaridae and rhizostome Kolpophorae (Jordano et al. unpublished data); and (5) the absence of nematocyst clusters on the 
exumbrella of newly released ephyrae (although present in other Daktyliophorae) (Jordano et al. unpublished data). Additionally, the only three rhizostome medusae reported from southern Brazil are Lychnorhiza lucerna, Stomolophus meleagris Agassiz, 1860, and Phyllorhiza punctata von Lendenfeld, 1884 (Morandini et al. 2005b, Oliveira et al. 2016). Live ephyrae of $P$. punctata, have a typical yellowish color pattern (Tronolone et al. 2002), which is lost in preserved specimens. Both ephyrae of $P$. punctata and S. meleagris do not possess serrated tips on marginal lappets (Calder 1982, Straehler-Pohl \& Jarms 2010). Based on all these features and the locality, we can affirm that the specimens found are ephyrae of L. lucerna.

It is curious that despite the relatively large number of estuarine and coastal plankton samples analyzed by cnidarian specialists in the occurrence range of L. lucerna (Vannucci 1951, Mianzan \& Cornelius 1999, Tronolone et al. 2002, Nogueira Jr 2012, Nagata et al. 2014) there were only two previous records of ephyrae of this species in nature (Nogueira Jr et al. 2019, Teixeira-Amaral et al. 2021). This fact and the low frequency of such ephyrae in our dataset ( $<1 \%$ of the samples) suggest that they are rare or difficult to detect through the small volume filtered (usually $<10 \mathrm{~m}^{-3}$ ) in these coastal samplings. Larger plankton nets with larger mesh sizes (i.e. $500 \mu \mathrm{m}$ ) and more frequent samplings efforts ( $\leq$ weekly) may enhance the capture of these ephyrae, respectively by increasing the volume of filtered water and the likelihood of collection during the occurrence periods of this short-lived life-cycle stage.

The presence of recent-released ephyrae of L. lucerna in the PLE suggests that scyphistomae, might be located close to this estuary. This finding highlights the role of the productive waters of the PLE, and adjacent coastal area, as nursery grounds for early life-cycle stages of this ecologically importantjellyfish species. The same can be true for other estuarine systems of South America, where aggregates of adult medusae occur seasonally in high densities (Schiariti et al. 2008, Nagata et al. 2009, Nogueira Jr \& Haddad 2017). Although the youngest ephyra (one to two days-old) was found inside the Patos Lagoon Estuary, it is still difficult to predict whether scyphistomae are inside or outside the PLE, as very few studies hint on the environmental preferences of scyphistomae of this species. A settlement experiment found that L. lucerna planula larvae settled both over natural and artificial substrata suggesting they do not have a clear preference (Schiariti et al. 2008). Some rhizostome species prefer artificial substrates and undersides of settling structures (Holst \& Jarms 2007). The coastal area surrounding the PLE, as well as most of Rio Grande do Sul State coastal area, is characterized by beaches with fine sedimentology, mainly fine sand quartz (Calliari 1998) that offer few areas of hard substratum for the settlement of planula larvae. Therefore, possible locations of scyphistomeae include: $i$ - the Parcel do Carpinteiro outcrop on the shallow shelf $(<20 \mathrm{~m}$ ) of the State; ii- docks surrounding the PLE; and iii- the Molhes da Barra breakwater, a man-made structure about 5 $\mathrm{km}$ long, made of rocks and concrete blocks that could serve as an ideal substratum for planulae settlement.

Because scyphistomae of L. lucerna and other species are cultivated in salinities between 15 and 35 (Schiariti et al. 2008, 2014, Willcox et al. 2007, Nagata et al. 2016, Carrizo et al. 2016), we believe the ideal conditions for those of $L$. lucerna may be found outside the PLE. Inside the PLE, the salinity oscillation is wide (from 0 to 35), and during the austral winter (JuneSeptember), salinities close to 0 predominates with extended periods of low salinity $(<5)$ during years under the influence of El Niño Southern 
Oscillation events (Teixeira-Amaral et al. 2017, 2021). No study has tested the tolerance and responses of scyphistomeae to the lower salinities $(<5)$ usually found inside the PLE. An alternative possibility for the maintenance of scyphistomae inside the Estuary could be the formation of podocysts, a dormant stage that persists under stressful conditions, such as lower salinity periods (Arai 1997, Dong et al. 2015), and unfavorable conditions of temperature and food availability (Schiariti et al. 2014).

Seasonality of L. lucerna medusae varies widely over the species distribution range. Larger medusae can be found year-round along the Southern Brazilian Bight $\left(23^{\circ}-25^{\circ} \mathrm{S}\right)$, with late-winter to spring (August-November) population increments (Nogueira Jr \& Haddad 2017, Morandini unpublished data). Along the northern Argentinean coast however, the species occurs only during warmer months (DecemberMay) (Schiariti et al. 2008). Nine out of the ten ephyrae in this study were collected during warmer months, under higher salinities (>30) and temperatures $\left(>20^{\circ} \mathrm{C}\right)$. These higher summer occurrences may be, in part, biased by the higher sampling frequency during this season (weakly in some years), but this possible seasonal pattern is also supported by observations of young and large medusae during warmer months, in the PLE. For example, seventeen days after the occurrence of ephyrae in December 2018, young medusae measuring between 2 and $5 \mathrm{~cm}$ of umbrella diameter were collected in the same region, using shrimp bottom trawls ( $\mathrm{N}$. et al. unpublished data). These occurrences of ephyrae along with young medusae in December suggest that the local population dynamics of L. lucerna is more similar to the pattern found in north Argentinean coast. This fact may also suggest that the temperature rise during late spring and early summer is an important factor triggering medusae production by scyphistomae of this species. Shifts in temperature are a key factor inducing strobilation for some species and often applied for scyphistomae in laboratory for obtaining ephyrae (Lucas et al. 2012, Helm 2018). Concerning L. lucerna scyphistomae in laboratrory, ephyrae are produced under constant temperature of $22^{\circ} \mathrm{C}$ (Schiariti et al. 2008), or when temperatures are risen from 16 to $22^{\circ} \mathrm{C}$, which are the same temperatures occurring during late spring to the onset of summer in the PLE (Teixeira-Amaral et al. 2021). On the other hand, the mid-winter occurrence of a single ephyra, at $16^{\circ} \mathrm{C}$ water temperature, as well as young medusa inside the PLE at $12^{\circ} \mathrm{C}$ (R.M. Nagata, personal observation) demonstrates that medusae production in the PLE can eventually occur year-round. These mid-winter occurrences have also expanded the expected range of temperature and salinity (Table II) for this species, which demonstrates a remarkable tolerance of L. lucerna to an ample variation in these physical parameters. Further studies should investigate the effects of environmental variability (e.g. drastic salinity changes) over scyphistomeae of L. lucerna, in order to support the elaboration of environment niche modelling and to access the species strategies to cope with possible changes on such variables. Finally, this study describes important information about temporal distribution and environmental preferences of the species, which reinforces the importance of long-term ecological research in coastal areas. Such information contributes to elucidate L. Lucerna recruitment periods, improving our knowledge about the species' life cycle and population dynamics.

\section{Ackowledgments}

The study was funded by Conselho Nacional de Desenvolvimento Científico e Tecnológico (CNPq/ MCTI) (Proc. no 403805/2012-0) and Fundação de Amparo à Pesquisa do Estado do Rio Grande do Sul (FAPERGS) (Proc. no 3122-2551/12-7) through the Brazilian 
Long-Term Ecological Research Program (BR-LTER) in the Patos Lagoon Estuary and Adjacent Coast, and by the Coordenação de Aperfeiçoamento de Pessoal de Nivel Superior-Brazil, Programa de Excelência Acadêmica (CAPES-PROEX). MAJ and ACM had financial support from Fundação de Amparo à Pesquisa do Estado de São Paulo (FAPESP 2015/25142-8, 2015/21007-9) and CNPq (304961/2016-7). RMN had the financial support of CNPq (438805/2018-6) and of the National Science Foundation (NSF 1536672). CAPES granted a scholarship to PTA. This is a contribution of Núcleo de Pesquisa em Biologia Marinha da Universidade de São Paulo (NP-BioMar USP) and of the INCT-Mar COI funded by CNPq (610012/2011-8).

\section{REFERENCES}

ABREU PC, MARANGONI J \& ODEBRECHT C. 2017. So close, so far: differences in long-term chlorophyll a variability in three nearby estuarine-coastal stations. Mar Biol Res 13: $9-21$.

ARAI MN. 1997. A functional biology of Scyphozoa. Chapman \& Hall, London, 316 p.

ASMUS ML. 1998. A Planície Costeira e a Lagoa dos Patos. In: Seeliger $U$ et al. (Eds), Os Ecossistemas Costeiro e Marinho do Sul do Brasil, Rio Grande: Ecoscientia, 9-12 p.

BERSANO JGF. 1994. Zooplâncton da zona de arrebentação de praias arenosas, situadas ao sul de Rio Grande, RS. Primavera de 90 e verão de 91, 163 p. Dissertação de Mestrado. Universidade Federal do Rio Grande, Rio Grande, RS. (Unpublished).

CALDER DR. 1982. Life history of the cannonball jellyfish, Stomolophus meleagris L. Agassiz, 1860 (Scyphozoa, Rhizostomida). Biol Bull 162: 149-162.

CALLIARI LJ. 1998. Ambientes Costeiros e Marinhos e sua Biota. Características geomorfológicas. In: Seeliger $U$ et al. (Eds), Os Ecossistemas Costeiro e Marinho do Sul do Brasil, Rio Grande: Ecoscientia, 101-104 p.

CARRIZO SS, SCHIARITI A, NAGATA RM \& MORANDINI AC. 2016. Preliminary observations on ephyrae predation by Lychnorhiza lucerna medusa (Scyphozoa; Rhizostomeae). Zool Gart 85: 74-83.

DONG J, SUN M, PURCELL JE, CHAI Y, ZHAO Y \& WANG A. 2015. Effect of salinity and light intensity on somatic growth and podocyst production in polyps of the giant jellyfish Nemopilema nomurai (Scyphozoa: Rhizostomeae). Hydrobiologia 754(1): 75-83.

GONÇALVES GRL, WOLF MR, DA COSTA RC \& CASTILHO AL. 2016. Decapod crustacean associations with scyphozoan jellyfish (Rhizostomeae: Pelagiidae) in the Southeastern Brazilian coast. Symbiosis 69(3): 193-198.

HELM R. 2018. Evolution and development of scyphozoan jellyfish. Biol Rev 93: 1228-1250.

HOLST S. 2012. Morphology and development of benthic and pelagic life stages of North Sea jellyfish (Scyphozoa, Cnidaria) with special emphasis on the identification of ephyra stages. Mar Biol 159: 2707-2722.

HOLST S \& JARMS G. 2007. Substrate choice and settlement preferences of planula larvae of five Scyphozoa (Cnidaria) from German Bight, North Sea. Mar Biol 151: 863.

JORDANO MA, MORANDINI AC \& NAGATA RM. 2020. IS phenotypic plasticity determined by temperature and fluid regime in filter-feeding gelatinous organisms? J Exp Mar Biol Ecol 520: 151238.

KAMINSKI SM. 2009. Mesozooplâncton do Estuário da Lagoa dos Patos e Zona Costeira Adjacente com Ênfase para os Copépodes Acartia tonsa, Pseudodiaptomus richardi e Notodiatomus incompositus (2000-2005), 139 p. Tese de Doutorado. Universidade Federal do Rio Grande, Rio Grande, RS.

LUCAS CH, GRAHAM WM \& WIDMER C. 2012. Jellyfish life histories: the role of polyps in forming and maintaining scyphomedusa populations. Adv Mar Biol 63: 33-196.

MARTINELLI FILHO JE, STAMPAR SN, MORANDINI AC \& MOSSOLIN EC. 2008. Cleaner shrimp (Caridea: Palaemonidae) associated with scyphozoan jellyfish. Vie Milieu 58 : 133-140.

MIANZAN HW \& CORNELIUS PFS. 1999. Scyphomedusae and Cubomedusae of the south Atlantic, In: Boltovskoy D (Ed), South Atlantic Zooplankton, Leiden: SPB Academic Publishing, 513-559 p.

MONTÚ M. 1980. Zooplâncton do estuário da Lagoa dos Patos. 1. Estrutura e variações temporais e espaciais da comunidade. Atlântica 4: 53-72.

MONTÚ M, DUARTE AK \& GLOEDEN I. 1998a. O Ambiente e a Biota do Estuário da Lagoa dos Patos. Zooplânncton. In: Seeliger $U$ et al. (Eds), Os Ecossistemas Costeiro e Marinho do Sul do Brasil, Rio Grande: Ecoscientia, 43-46 p.

MONTÚ M, GLOEDEN I, DUARTE AK \& RESGALLA JR C. 1998b. Ambientes Costeiros e Marinhos e sua Biota. Zooplâncton. In: Seeliger U et al. (Eds), Os Ecossistemas Costeiro e Marinho do Sul do Brasil, Rio Grande: Ecoscientia, 123$127 \mathrm{p}$. 
MORANDINI AC, ASCHER D, STAMPAR SN \& FERREIRA JFV. 2005b. Cubozoa e Scyphozoa (Cnidaria: Medusozoa) de águas costeiras do Brasil. Iheringia (Zool) 95: 281-294.

MORANDINI AC, MARTORELLI SR, MARQUES AC \& SILVEIRA FL. 2005a. Digenean metacercaria (Trematoda, Digenea, Lepocreadiidae) parasitizing "coelenterates" (Cnidaria, Scyphozoa and Ctenophora) from Southeastern Brazil. Braz J Oceanogr 53: 39-45.

MORANDINI AC, SOARES MO, MATTHEWS-CASCON H \& MARQUES AC. 2006. A survey of the Scyphozoa and Cubozoa (Cnidaria, Medusozoa) from the Ceará coast (NE Brazil). Biota Neotrop 6(2): 1-8.

MUXAGATA E, AMARAL WJA \& BARBOSA CN. 2012. Acartia tonsa production in the Patos Lagoon estuary, Brazil. ICES I Mar Sci 69(3): 475-482.

NAGATA RM, HADDAD MA \& NOGUEIRA JR M. 2009. The nuisance of medusa (Cnidaria: Medusozoa) to shrimp trawls in central part of Southern Brazilian Bight, from the perspective of artisanal fisherman. Pan-Am J Aquat Sci 4: 312-325.

NAGATA RM \& MORANDINI AC. 2018. Diet, prey selection, and individual feeding rates of the jellyfish Lychnorhiza lucerna (Scyphozoa, Rhizostomeae). Mar Biol 165: 187.

NAGATA RM, MORANDINI AC, COLIN SP, MIGOTTO AE \& COSTELLO $J$ H. 2016. Transitions in morphologies, fluid regimes, and feeding mechanisms during development of the medusa Lychnorhiza lucerna. Mar Ecol Prog Ser 557: 145-159.

NAGATA RM, MOREIRA MZ, PIMENTEL CR \& MORANDINI AC. 2015. Food web characterization based on $\delta 15 \mathrm{~N}$ and $\delta 13 \mathrm{C}$ reveals isotopic niche partitioning between fish and jellyfish in a relatively pristine ecosystem. Mar Ecol Prog Ser 519: 13-27.

NAGATA RM, NOGUEIRA JR M \& HADDAD MA. 2014. Faunistic survey of Hydromedusae (Cnidaria, Medusozoa) from the coast of Paraná State, Southern Brazil. Zootaxa 3768: 291-326.

NOGUEIRA JR M. 2012. Gelatinous zooplankton fauna (Cnidaria, Ctenophora and Thaliacea) from Baía da Babitonga (southern Brazil). Zootaxa 3398: 1-21.

NOGUEIRA JR M \& HADDAD MA. 2005. Lychnorhiza lucerna Haeckel (Scyphozoa, Rhizostomeae) and Libinia ferreirae Brito Capello (Decapoda, Majidae) association in southern Brazil. Rev Bras de Zool 22: 908-912.

NOGUEIRA JR M, DA COSTA BSP, MARTINEZ TA, BRANDINI FP \& MIYASHITA LK. 2019. Diversity of gelatinous zooplankton (Cnidaria, Ctenophora, Chaetognatha and Tunicata) from a subtropical estuarine system, southeast Brazil. Mar Biodiv 49: 1283-1298.
NOGUEIRA JR M \& HADDAD MA. 2017. Seasonal distribution, abundance and biomass of large medusae in subtropical coast of Brazil. In: Mariotini L (Ed), Jellyfish: ecology, distribution patterns and human interactions, New York: Nova Publishers, New York, USA, p. 3-26.

ODEBRECHT C, SECCHI ER, ABREU PC, MUELBERT JH \& UIBLEIN F. 2017. Biota of the Patos Lagoon estuary and adjacent marine coast: long-term changes induced by natural and human-related factors. Mar Biol Res 13(1): 3-8.

OLIVEIRA OMP ET AL. 2016. Census of Cnidaria (Medusozoa) and Ctenophora from South American marine waters. Zootaxa 4194: 1-256.

ÖSTMAN C. 2000. A guideline to nematocyst nomenclature and classification, and some notes on the systematic value of nematocysts. Sci Mar 64: 31-46.

PALMÉN E. 1954. Seasonal occurrence of ephyrae and subsequent instars of Aurelia aurita (L.) in the shallow waters of Tvärminne, S. Finland. Arch Soc Zool Bot Fenn Vanamo 8: 122-131.

PITT KA. 2000. Life history and settlement preferences of the edible jellyfish Catostylus mosaicus (Scyphozoa: Rhizostomeae). Mar Biol 136: 269-279.

PURCELL JE, UYE SI \& LO W. 2007. Anthropogenic causes of jellyfish blooms and their direct consequences for humans: a review. Mar Ecol Prog Ser 350: 153-174.

RUSSELL FS. 1970. The medusae of the British Isles II. Pelagic Scyphozoa with a supplement to the first volume on hydromedusae. Cambridge University Press, London, $255 \mathrm{p}$.

SCHIARITI A, DUTTO SM, PEREYRA DY, FAILLA-SIQUIER G \& MORANDINI AC. 2018. Medusae (Scyphozoa and Cubozoa) from southwestern Atlantic and Subantarctic region (32$60^{\circ} \mathrm{S}, 34-70^{\circ} \mathrm{W}$ ): species composition, spatial distribution and life history traits. Lat Am J Aquat Res 46(2): 240-257.

SCHIARITI A, KAWAHARA M, UYE S \& MIANZAN H. 2008. Life cycle of the jellyfish Lychnorhiza lucerna (Scyphozoa: Rhizostomeae). Mar Biol 156: 1-12.

SCHIARITI A, MORANDINI AC, JARMS G, PAES RG, FRANKE S \& MIANZAN H. 2014. Asexual reproduction strategies and blooming potential in Scyphozoa. Mar Ecol Prog Ser 510: 241-253.

SILVEIRA FL \& MORANDINI AC. 1997. Nausithoe aurea n. sp. (Scyphozoa, Coronatae, Nausithoidae), a species with two pathways of reproduction after strobilation: sexual and asexual. Contrib Zool 66: 235-246.

SINQUE C \& MUELBERT JH. 1998. O Ambiente e a Biota do Estuário da Lagoa dos Patos. In: Seeliger U et al. (Eds), 
Os Ecossistemas Costeiro e Marinho do Sul do Brasil, Rio Grande: Ecoscientia, p. 56-60.

STRAEHLER-POHL I \& JARMS G. 2010. Identification key for young ephyrae: a first step for early detection of jellyfish blooms. Hydrobiologia 645: 3-21.

STRAEHLER-POHL I, WIDMER CL \& MORANDINI AC. 2011. Characterizations of juvenile stages of some semaeostome Scyphozoa (Cnidaria), with recognition of a new family (Phacellophoridae). Zootaxa 2741: 1-37.

TEIXEIRA-AMARAL P, AMARAL WJA, ORTIZ DO, AGOSTINI VO \& MUXAGATA E. 2017. The mesozooplankton of the Patos Lagoon Estuary, Brazil: trends in community structure and secondary production. Mar Biol Res 13(1): 48-61.

TEIXEIRA-AMARAL P, LEMOS VR, MUXAGATA E \& NAGATA RM. 2021. Temporal dynamics of mesoplanktonic cnidarians in a subtropical estuary: Environmental drivers and possible trophic effects. Estuar Coast Shelf S 249: 107076.

TOYOKAWA M, SHIBATA M, CHENG J-H, LI H-Y, LING J-Z, LIN N, LIU Z-L, ZHANG Y, SHIMIZU M \& AKIYAMA H. 2012. First record of wild ephyrae of the giant jellyfish Nemopilema nomurai. Fish Sci 78: 1213-1218.

TRONOLONE VB, MORANDINI AC \& MIGOTTO AE. 2002. On the occurrence of scyphozoan ephyrae (Cnidaria, Scyphozoa, Semaeostomeae and Rhizostomeae) in the southeastern Brazilian coast. Biota Neotrop 2: 1-18.

UCHIDA T. 1926. The anatomy and development of a rhizostome medusa, Mastigias papua L. Agassiz, with observations on the phylogeny of Rhizostomae. J Fac Sci Univ Tokyo Sect 4 Zool 1: 45-95.

VANNUCCI M. 1951. Hydrozoa e Scyphozoa existentes no Instituto Paulista de Oceanografia I. Bol Inst Oceanogr 2(1): 67-98.

WILLCOX S, MOLTSCHANIWSKYJ NA \& CRAWFORD C. 2007. Asexual reproduction in scyphistomae of Aurelia sp.: Effects of temperature and salinity in an experimental study. J Exp Mar Biol Ecol 353: 107-114.

\section{How to cite}

NAGATA RM, TEIXEIRA-AMARAL P, LEMOS VR, JORDANO MA, MUXAGATA E \& MORANDINI AC. 2021. First description of wild-collected ephyrae of Lychnorhiza lucerna (Cnidaria, Scyphozoa). An Acad Bras Cienc 93: e20190574. DOI 10.1590/0001-3765202120190574.

Manucript received on May 20, 2019;

accepted for publication on October 7, 2019

\section{RENATO M. NAGATA ${ }^{1}$}

https://orcid.org/0000-0002-4125-3958

\section{PRISCILA TEIXEIRA-AMARAL ${ }^{1}$}

https://orcid.org/0000-0001-7141-3273

\section{VITÓRIA R. LEMOS ${ }^{1}$}

https://orcid.org/0000-0002-0848-6880

\section{MAYARA A. JORDANO ${ }^{2}$}

https://orcid.org/0000-0003-0665-9917

\section{ERIK MUXAGATA ${ }^{1}$}

https://orcid.org/0000-0002-4210-5252

\section{ANDRÉ C. MORANDINII ${ }^{2,3}$}

https://orcid.org/0000-0003-3747-8748

${ }^{1}$ Laboratório de Zooplâncton, Instituto de Oceanografia, Universidade Federal do Rio Grande, Av. Itália, km 8, 96203-000 Rio Grande, RS, Brazil

${ }^{2}$ Departamento de Zoologia, Instituto de Biociências, Universidade de São Paulo, Rua do Matão, trav. 14, 101, 05508-090 São Paulo, SP, Brazil

${ }^{3}$ Centro de Biologia Marinha, Universidade de São Paulo, Rodovia Manuel Hypólito do Rego, km 131.5, 11612-109 São Sebastião, SP, Brazil

\section{Correspondence to: Renato Mistuo Nagata}

E-mail: renatonagata@gmail.com

\section{Author contributions}

$R$ Nagata determined the species of ephyrae as L. lucerna and wrote the first draft of this study. P Teixeira-Amaral, E Muxagata, and $V$ Lemos contributed with the collection, analyzes, and separation of ephyrae from plankton samples. $V$ Lemos contributed with morphometric analyses of the ephyrae. A. Morandini and M Jordano contributed to the determination of the species of ephyrae and with the comparison of wildcollected with laboratory-reared specimens. All authors contributed reviewing the manuscript and approved its final version.

\section{(c) BY}

